\title{
ASSESSMENT OF ABUNDANCE AND DISTRIBUTION OF THE ROMAN SNAIL (HELIX POMATIA LINNAEUS, 1758) IN KUJAWSKO-POMORSKIE VOIVODESHIP
}

\author{
JERZY BŁOSZYK ${ }^{1,4}$, MAREK MACHNIKOWSKI ${ }^{2}$, AGNIESZKA NAPIERAŁA $^{1}$ *, BARTŁOMIEJ GOŁDYN ${ }^{1}$, \\ ELIZA RYBSKA ${ }^{3}$, KAZIMIERZ STEPPCZAK ${ }^{1}$, KRYSTYNA SZYBIAK ${ }^{1}$, SZYMON KONWERSKI $^{4}$, \\ KORNELIA LESZCZYŃSKA-DEJA ${ }^{2}$, MAGDALENA DYLEWSKA ${ }^{4}$, TOMASZ KALINOWSKI ${ }^{1}$, ANNA JANKOWIAK ${ }^{1}$
}

\footnotetext{
${ }^{1}$ Department of General Zoology, Adam Mickiewicz University, Institute of Environmental Biology, Umultowska 89, 61-614 Poznań, Poland

${ }^{2}$ Regional Administration of Environment Protection in Bydgoszcz, Dworcowa 63, 85-950 Bydgoszcz, Poland

${ }^{3}$ Laboratory for Nature and Biology Education, Adam Mickiewicz University, Umultowska 89, 61-614 Poznań, Poland

${ }^{4}$ Natural History Collections, Adam Mickiewicz University, Umultowska 89, 61-614 Poznań, Poland

*Corresponding author e-mail: agan@amu.edu.pl
}

ABSTRACT: Populations of Helix pomatia L. in Poland have been commercially exploited since 1951; the snails are mostly exported. The growing interest in the Roman snail on the European market has resulted in its increased exploitation, in some areas leading to a considerable decrease in its abundance. Introducing export quota in 1964 did not prevent overexploitation. Precise assessment of abundance and distribution of the Roman snail populations in areas where it is exploited is necessary. In 2009 the team from the Faculty of Biology, Adam Mickiewicz University in Poznań, conducted a preliminary assessment and mapping of the abundance and distribution of the Roman snail populations in Kujawsko-Pomorskie voivodeship. Most populations showed a low density. From scientific point of view the most reasonable solution would be to suspend exploitation in 2010 and continue monitoring, while decisions to issue permits for limited exploitation should be postponed till 2011. It would enable a more detailed estimation of the non-exploited populations and an assessment of losses resulting from exploitation of controlled reference populations. In this way acceptable limits of annual commercial collecting could be set for particular parts of the voivodeship.

KEY WORDS: Helix pomatia, population resources, exploitation quota, species protection, exploitation limits, purchase centres

\section{INTRODUCTION}

The Roman snail (Helix pomatia Linnaeus, 1758), the largest terrestrial snail in the country, is the only commercially exploited mollusc in Poland. Its exploitation started after World War II, in 1951. It was initiated by the Forest Production Cooperative "LAS", and initially included the Poznań, Bydgoszcz and Wrocław voivodeships (URBAŃSKI 1963, STĘPCZAK 1976). The growing interest in the Roman snail on the European market caused its increased exploitation and expansion of the exploited areas (STEPCZAK 1976). In 1961-1974 the annual export to France and partly
Germany was ca. 300 tons of snails (STEPCZAK 1976). Only live specimens were exported, and no attempts at processing were made in the country.

The exploitation was the greatest in Lower Silesia (ca. 31\% of the country's yield), in the region of Szczecin (ca. $15 \%$ ), in Wielkopolska $(9.6 \%)$ and the environs of Zielona Góra $(8.3 \%)$. The yield from the area corresponding to the present-day Kujawsko-Pomorskie voivodeship was nearly $3 \%$, which made it the tenth snail harvest region in the country (STEPCZAK 1976). Already in 1960-1963 the increasing intensity of the 
Roman snail exploitation in Poland caused a decline or even disappearance of the species in some areas (BIULETYN CIS 1962, URBAŃSKI 1963). In response to this situation the Central Inspectorate for Standardisation issued new export standards, the acceptable size being shell diameter exceeding $30 \mathrm{~mm}$ (till 1963 snails above $28 \mathrm{~mm}$ were purchased). At the same time the collecting season was limited to May. The standards were introduced in 1964, and are still in force.

Considerable changes in the management of the Roman snail resources took place in the 1980s and after 1990. Development of processing in Poland and cessation of export of live snails, suggested much earlier (STEPCZAK 1976), had a favourable effect. The other changes were and still are negative. Numerous firms were established, dealing exclusively with Roman snail exploitation and processing, and seeking fast profit. As a result the Roman snail exploitation in many regions became very intensive. This was favoured by frequent unemployment periods when many people started collecting the snails in order to obtain even a very small income. The number of people owning cars also increased, and the snails could be delivered to the purchase centres from increasingly greater distances and in larger quantities.

In view of these facts it became necessary to assess the abundance and distribution of the Roman snail populations in the areas where it was exploited. The results should make it possible to determine the acceptable exploitation quota of this partially protected species, at the level not dangerous to the natural populations.

On the commission of the Regional Administration of Environment Protection in Bydgoszcz the team from the Department of General Zoology, Natural History Collections and Laboratory for Nature and Biology Education, Faculty of Biology, Adam Mickiewicz University in Poznań, conducted a preliminary assessment of abundance and distribution of the Roman snail populations in Kujawsko-Pomorskie voivodeship. The results provide a starting point for constant monitoring of abundance and distribution of the species in particular communes of the voivodeship planned for 2010-2015.

\section{MATERIAL AND METHODS}

The studies included all the communes in $\mathrm{Ku}$ jawsko-Pomorskie voivodeship. Field work was conducted from May 3rd till July 2nd 2009. At least three sites of potential occurrence of the Roman snail were selected in each commune, based on satellite maps, and then verified in the field. Additionally, other potential sites were checked during field work. In each site all observed individuals were collected from an area of 1-2 ares during 10 minutes. It was assumed that a team of 3-4 people could collect up to $35 \%$ of all snails present in the examined plot. Usually, a single collector can collect $15-20 \%$ of individuals in the area (STEPCZAK 1976). The individuals were counted, weighed, their size was noted (within standard versus below standard ratio) and divided into mature (growth terminated) and juvenile, based on the presence/absence of lip. The snails were then released in the col-

lection site. The resulting estimated relative densities served as the basis for distribution and abundance maps. Five categories of communes were distinguished based on the number of snails per 1 are plot:

1. Communes with Roman snail resources of commercial size: $>30$ individuals,

2. Communes with abundant Roman snail populations: $30-11$ individuals,

3. Communes with moderately rich Roman snail populations: 4-10 individuals,

4. Communes with poor Roman snail populations,

5. Communes where no Roman snail was found.

Data from the Regional Administration of Environment Protection in Bydgoszcz on the distribution of Roman snail purchase centres 2001-2008 served as the basis for maps (Figs 2-6) of the purchase centre distribution.

\section{RESULTS}

\section{SPATIAL STRUCTURE OF THE ROMAN SNAIL DISTRIBUTION IN KUJAWSKO-POMORSKIE VOIVODESHIP}

Out of more than 280 plots verified in the field, only 53 yielded 30 and more individuals of the Roman snail. In the remaining plots single individuals were observed; few plots yielded from several to about a dozen snails. No $H$. pomatia was found in 105 of the all examined plots. Fig. 1 presents the five categories of density in individual communes. Three distinct groups of communes with rich Roman snail resources (more than 30 individuals/1 are) could be distingished in Kujawsko-Pomorskie voivodeship in the studied period.

The first and largest group includes the communes of the south-western part of the voivodeship (arrangement of communes alphabetical): Barcin, Dąbrowa, Dąbrowa Biskupia, Dobre, Inowrocław, Janikowo, Janowiec Wielkopolski, Kcynia, Kruszwica, 


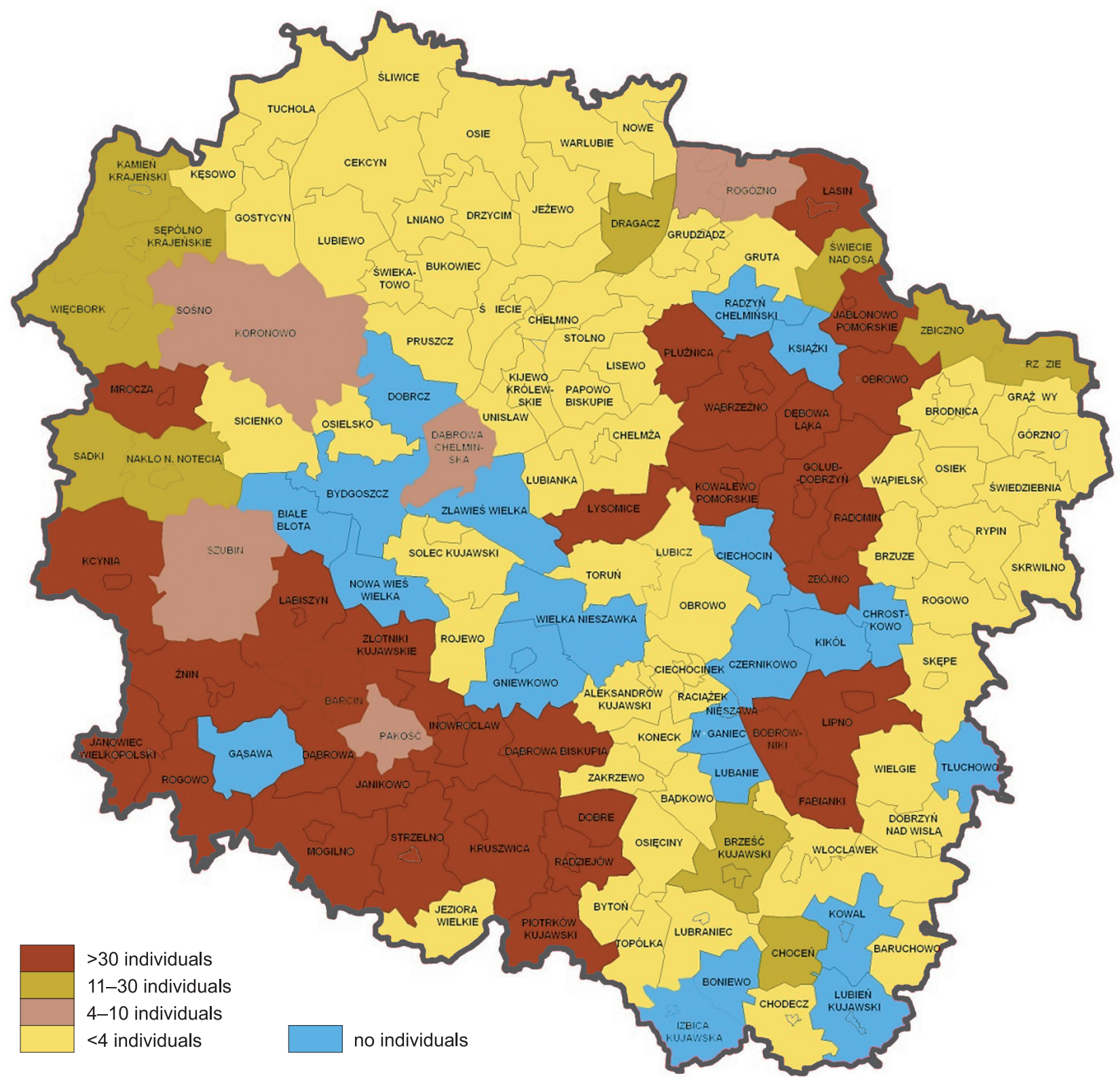

Fig. 1. Structure of Roman snail distribution in the communes of Kujawsko-Pomorskie voivodeship in May-June 2009

Łabiszyn, Mogilno, Piotrków Kujawski, Radziejów, Rogowo, Strzelno, Złotniki Kujawskie, Żnin. The second group includes communes located in the north-eastern part of the area: Bobrowo, Dębowa Łąka, Golub-Dobrzyń, Jabłonowo Pomorskie, Kowalewo Pomorskie, Łasin, Łysomice, Płużnica, Radomin, Wąbrzeźno, Zbójno. The third and smallest group includes three communes in the eastern part of the voivodeship: Bobrowniki, Fabianki and Lipno.

Besides, considerable Roman snail resources were found in communes Dąbrowa Chełmińska, Koronowo, Pakość, Rogoźno, Sośno, Szubin, with populations of a density from 4 to 13 individuals/ 1 are. Only single individuals of the Roman snail were found in the remaining communes during the inventory.

\section{LOCATION OF PURCHASE CENTRES AND SPATIAL DISTRIBUTION OF ROMAN SNAIL RESOURCES}

The information on the purchase centre distribution in Kujawsko-Pomorskie voivodeship in 2001-2008, obtained from the Regional Administration of Environment Protection in Bydgoszcz, served to select the communes with Roman snail populations which were abundant enough to make commercial collecting profitable.

Figs 2-6 present the distribution of communes which in 2001-2008 held purchase centres. It largely corresponds to the abundant resources of the Roman snail in individual communes (cf. Fig. 1). Data of 2001 are imprecise (no location of purchase centres 
Table 1. Numer of Roman snail purchase centres in the communes of Kujawsko-Pomorskie voivodeship in 2001-2008 and size of purchase in each year (data from Regional Administration of Environment Protection in Bydgoszcz): ? - data uncertain or no data

\begin{tabular}{|c|c|c|c|c|c|c|c|c|c|c|}
\hline No. & Commune & 2001 & 2002 & 2003 & 2004 & 2005 & 2006 & 2007 & 2008 & $\begin{array}{c}\text { Numer of } \\
\text { purchase } \\
\text { centres }\end{array}$ \\
\hline 1 & Gostycyn & 1 & 1 & 1 & 1 & 2 & 1 & 1 & 2 & 10 \\
\hline 2 & Mrocza & & 1 & 1 & 1 & 1 & 1 & 2 & 2 & 9 \\
\hline 3 & Mogilno & & 1 & 1 & 1 & 1 & 1 & 1 & 1 & 7 \\
\hline 4 & Pakość & & 1 & 1 & & 2 & 2 & 2 & 1 & 9 \\
\hline 5 & Barcin & & 1 & 1 & & 2 & 2 & 1 & 1 & 8 \\
\hline 6 & Strzelno & & 1 & 1 & & 1 & 1 & 1 & 1 & 6 \\
\hline 7 & Nakło nad Notecią & & & & 2 & 4 & 2 & 1 & 3 & 12 \\
\hline 8 & Kcynia & & & & 1 & 2 & 2 & 1 & 1 & 7 \\
\hline 9 & Złotniki Kujawskie & & & & & 2 & 2 & 1 & & 5 \\
\hline 10 & Sadki & & & & & 2 & 2 & 2 & 3 & 9 \\
\hline 11 & Toruń & & & & & 2 & 2 & 3 & 2 & 9 \\
\hline 12 & Świecie & & & & 1 & 3 & 1 & 3 & & 8 \\
\hline 13 & Zbiczno & & & & & 2 & 2 & 2 & 2 & 8 \\
\hline 14 & Brodnica & & & & & 3 & 2 & 3 & & 8 \\
\hline 15 & Brzozie & & & & & 1 & 2 & 3 & 2 & 8 \\
\hline 16 & Kruszwica & & & & & 2 & 2 & 2 & 2 & 8 \\
\hline 17 & Kamień Krajeński & & & & & 3 & 1 & 1 & 2 & 7 \\
\hline 18 & Golub-Dobrzyń & & & & & 2 & 2 & 2 & 1 & 7 \\
\hline 19 & Gniewkowo & & & & 1 & 3 & 1 & 2 & & 7 \\
\hline 20 & Inowrocław & & & & & 2 & 2 & 2 & 1 & 7 \\
\hline 21 & Osiek & & & & & 2 & 2 & 1 & 1 & 6 \\
\hline 22 & Żnin & & & & & 2 & 2 & 1 & 1 & 6 \\
\hline 23 & Czernikowo & & & & 1 & 2 & 1 & 2 & & 6 \\
\hline 24 & Kikół & & & & 1 & 2 & 1 & 2 & & 6 \\
\hline 25 & Cekcyn & & & & & 1 & 1 & 2 & 1 & 5 \\
\hline 26 & Górzno & & & & & 1 & 2 & 1 & 1 & 5 \\
\hline 27 & Bobrowniki & & & & 1 & 2 & 1 & 1 & & 5 \\
\hline 28 & Wąbrzeźno & & & & & 1 & 1 & 1 & 1 & 4 \\
\hline 29 & Tuchola & & & & 1 & 2 & & 1 & & 4 \\
\hline 30 & Jeżewo & & & & & 2 & 1 & 1 & & 4 \\
\hline 31 & Więcbork & & & & & 2 & 1 & 1 & & 4 \\
\hline 32 & Osie & & & & & 1 & 1 & 1 & & 3 \\
\hline 33 & Warlubie & & & & & 1 & 1 & 1 & & 3 \\
\hline 34 & Nowe & & & & & 1 & 1 & 1 & & 3 \\
\hline 35 & Drzycim & & & & & 1 & 1 & 1 & & 3 \\
\hline 36 & Grudziądz & & & & & 1 & 1 & 1 & & 3 \\
\hline 37 & Rogoźno & & & & & 1 & 1 & 1 & & 3 \\
\hline 38 & Łasin & & & & & 1 & 1 & 1 & & 3 \\
\hline 39 & Gruta & & & & & 1 & 1 & 1 & & 3 \\
\hline 40 & Świecie nad Osą & & & & & 1 & 1 & 1 & & 3 \\
\hline 41 & Chełmno & & & & & 1 & 1 & 1 & & 3 \\
\hline 42 & Stolno & & & & & 1 & 1 & 1 & & 3 \\
\hline
\end{tabular}




\begin{tabular}{|c|c|c|c|c|c|c|c|c|c|c|}
\hline No. & Commune & 2001 & 2002 & 2003 & 2004 & 2005 & 2006 & 2007 & 2008 & $\begin{array}{c}\text { Numer of } \\
\text { purchase } \\
\text { centres }\end{array}$ \\
\hline 43 & $\begin{array}{l}\text { Radzyń Chełmiński } \\
\text { (Radzymin) }\end{array}$ & & & & & 1 & 1 & 1 & & 3 \\
\hline 44 & Jabłonowo Pomorskie & & & & & 1 & 1 & 1 & & 3 \\
\hline 45 & Unisław & & & & & 1 & 1 & 1 & & 3 \\
\hline 46 & Papowo Biskupie & & & & & 1 & 1 & 1 & & 3 \\
\hline 47 & Lisewo & & & & & 1 & 1 & 1 & & 3 \\
\hline 48 & Szubin & & & & & 1 & 1 & 1 & & 3 \\
\hline 49 & Łabiszyn & & & & & 1 & 1 & 1 & & 3 \\
\hline 50 & Solec Kujawski & & & & & 1 & 1 & 1 & & 3 \\
\hline 51 & $\begin{array}{l}\text { Janowiec } \\
\text { Wielkopolski }\end{array}$ & & & & & 1 & 1 & 1 & & 3 \\
\hline 52 & Rogowo & & & & & 1 & 1 & 1 & & 3 \\
\hline 53 & Gąsawa & & & & & 1 & 1 & 1 & & 3 \\
\hline 54 & Janikowo & & & & & 1 & 1 & 1 & & 3 \\
\hline 55 & Lubraniec & & & & & 1 & 1 & 1 & & 3 \\
\hline 56 & Brześć Kujawski & & & & & 1 & 1 & 1 & & 3 \\
\hline 57 & Włocławek & & & & & 1 & 1 & 1 & & 3 \\
\hline 58 & Dobrzyń nad Wisłą & & & & & 1 & 1 & 1 & & 3 \\
\hline 59 & Izbica Kujawska & & & & & 1 & 1 & 1 & & 3 \\
\hline 60 & Choceń & & & & & 1 & 1 & 1 & & 3 \\
\hline 61 & Kowal & & & & & 1 & 1 & 1 & & 3 \\
\hline 62 & Chodecz & & & & & 1 & 1 & 1 & & 3 \\
\hline 63 & Koronowo & & & & & 1 & & & 2 & 3 \\
\hline 64 & Chełmża & & & & & 1 & 1 & & & 2 \\
\hline 65 & Lipno & & & & 1 & & & 1 & & 2 \\
\hline 66 & Fabianki & & & & & 1 & 1 & & & 2 \\
\hline 67 & Piotrków Kujawski & & 1 & 1 & & & & & & 2 \\
\hline 68 & Jeziora Wielkie & & & & & 1 & 1 & & & 2 \\
\hline 69 & Dąbrowa & & & & & 1 & 1 & & & 2 \\
\hline 70 & Kowalewo Pomorskie & & & & & 2 & & & & 2 \\
\hline 71 & Sępólno Krajeńskie & & & & & 1 & & & & 1 \\
\hline 72 & Lubiewo & & & & & & & 1 & & 1 \\
\hline 73 & Świekatowo & & & & & & & 1 & & 1 \\
\hline 74 & Bukowiec & & & & & & & 1 & & 1 \\
\hline 75 & Sośno & & & & & 1 & & & & 1 \\
\hline 76 & Pruszcz & & & & & & & 1 & & 1 \\
\hline 77 & Bobrowo & & & & & 1 & & & & 1 \\
\hline 78 & Brzuze & & & & & 1 & & & & 1 \\
\hline 79 & Rypin & & & & & 1 & & & & 1 \\
\hline 80 & Raciążek & & & & & & & 1 & & 1 \\
\hline 81 & Skępe & & & & & & & 1 & & 1 \\
\hline 82 & Lubanie & & & & & & 1 & & & 1 \\
\hline 83 & Topólka & & 1 & & & & & & & 1 \\
\hline & Total & 1 & 8 & 7 & 13 & 104 & 82 & 88 & 34 & 337 \\
\hline & Yield [kg] & $34,618.6$ & $24,041.5$ & 20,358 & 15,236 & $29,000 ?$ & 19,000 & ?? & 19,850 & \\
\hline
\end{tabular}




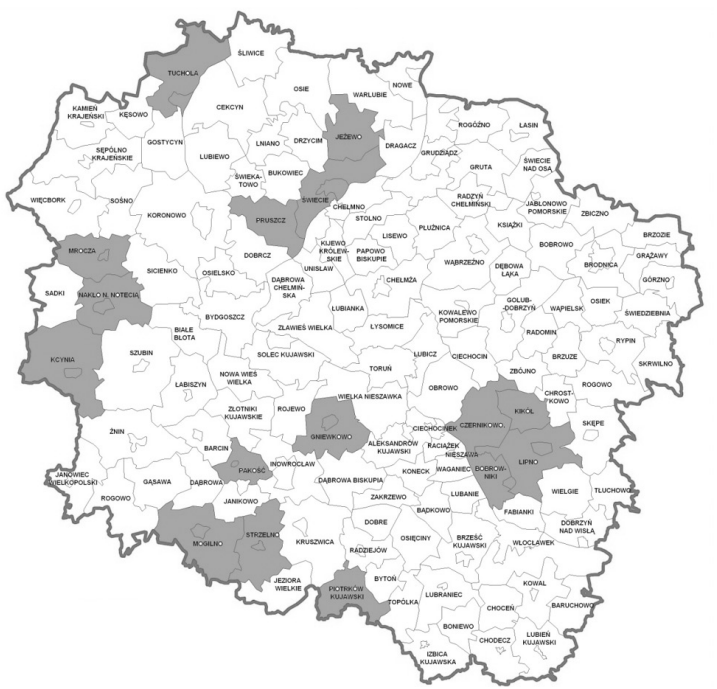

Fig. 2. Communes with Roman snail purchase centres (darker) in 2001-2004

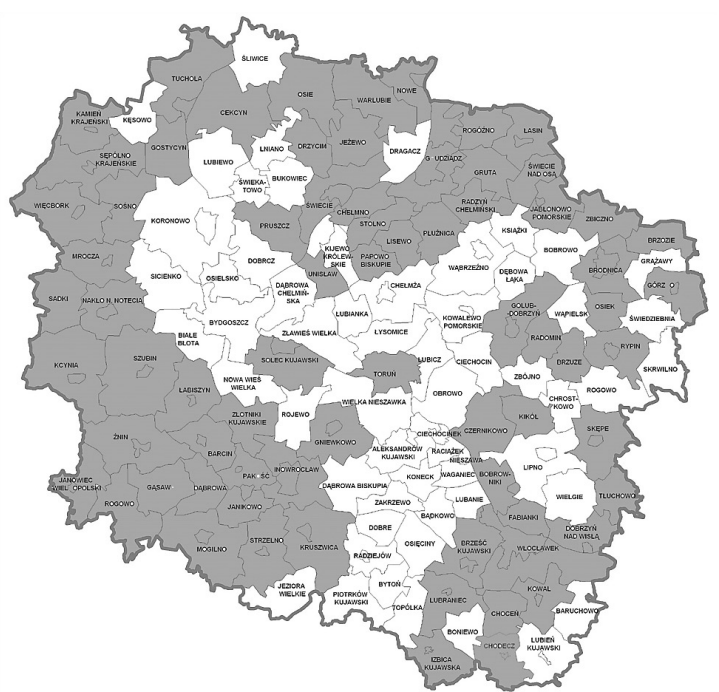

Fig. 3. Communes with Roman snail purchase centres (darker) in 2005

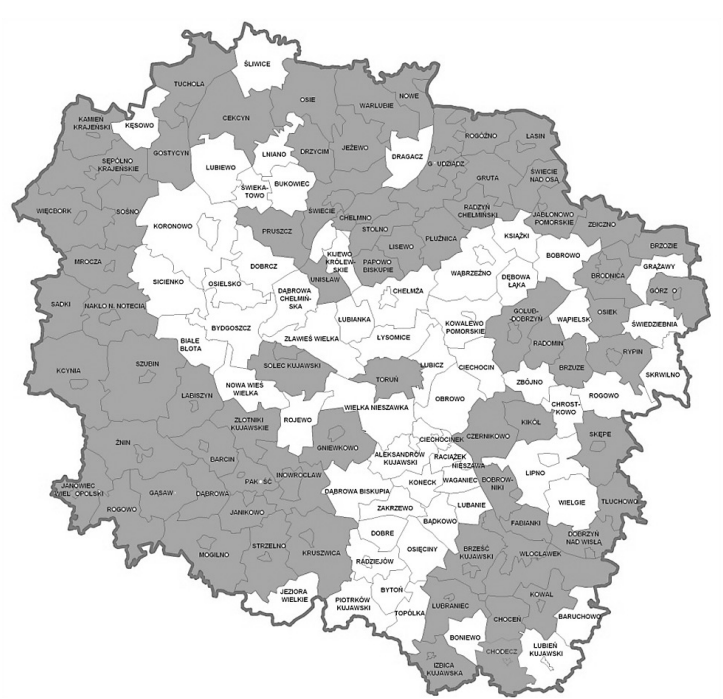

Fig. 4. Communes with Roman snail purchase centres (darker) in 2006

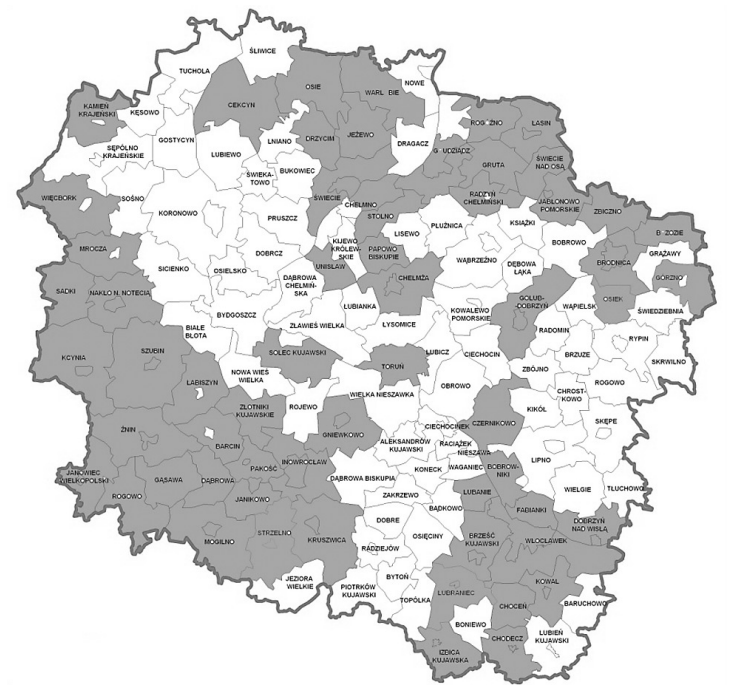

Fig. 5. Communes with Roman snail purchase centres (darker) in 2007

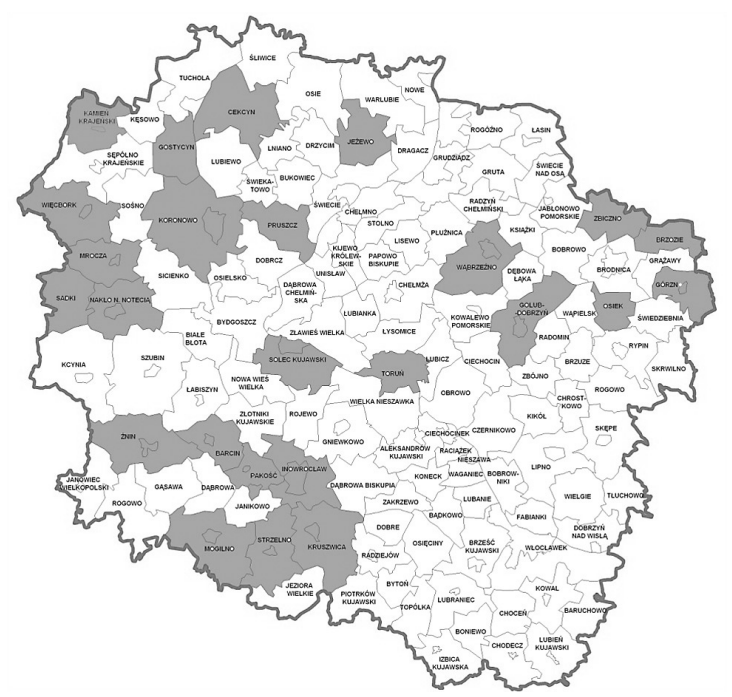

Fig. 6. Communes with Roman snail purchase centres (darker) in 2008

given). In subsequent years, till 2004, such centres were located only in a few communes. More purchase centres appeared in Kujawsko-Pomorskie voivodeship since 2005 (Fig. 3). They concentrated mainly on the margins of the voivodeship. The central part, which according to the inventory has no commercially valuable Roman snail populations, is also devoid of purchase centres.

Table 1 shows a list of purchase centres in individual communes in 2001-2008. Such centres functioned in 83 communes $(58 \%$ of all communes of the voivodeship). Their number in individual communes in a year varied from one to four. Only in one commune - Gostycyn - purchase centres were opened every year starting with 2001. Likewise, in communes Mrocza and Mogilno, purchase centres operated since 2002. The maximum number of purchase centres (12) in 2001-2008 was noted in communes Nakło on the Noteć (2004-2008) and Gosty- 
Table 2. Characteristics of selected Roman snail populations: N - number of specimens; J:A - juvenile/adult ratio [\%]; DM:DD - size structure of adults [in \%], (DM - individuals below standard size, DD - individual of standard size $) ;$ Bio ${ }^{\text {tot }}$ - biomass of collected individuals [g], Bio ${ }^{\text {ind }}$ - mean individual biomass (mean $\pm \mathrm{SD}$ ) [g]; $\mathrm{n} / \mathrm{kg}$ - number of individuals required to obtain $1 \mathrm{~kg}$ of snails; ind./are - density per $100 \mathrm{~m}^{2}$

\begin{tabular}{|c|c|c|c|c|c|c|c|c|}
\hline Locality & Commune & $\mathrm{N}$ & $\mathrm{J}: \mathrm{A}$ & DM:DD & $\mathrm{Bio}^{\mathrm{tot}}$ & $\mathrm{Bio}^{\text {ind }}$ & $\mathrm{n} / \mathrm{kg}$ & $\begin{array}{c}\text { ind./ } \\
100 \mathrm{~m}^{2}\end{array}$ \\
\hline Barcin - UTM: YU00 11 & Barcin & 32 & $26: 74$ & 9:91 & 679 & $24.4 \pm 4.5$ & 41 & 27.1 \\
\hline Piechcin - UTM: YU00 11 & Barcin & 167 & 28:72 & - & - & - & - & 11.0 \\
\hline Pturek - UTM: YU00 11 & Barcin & 53 & $53: 47$ & - & - & - & - & 6.2 \\
\hline Małki I - UTM: CE80 30 & Bobrowo & 97 & $69: 31$ & - & - & - & - & 26.3 \\
\hline Małki II - UTM: CE80 30 & Bobrowo & 97 & 34:66 & $10: 90$ & 1,950 & $22.7 \pm 3.4$ & 44 & 28.9 \\
\hline Laski Wielkie - UTM: XU93 01 & Dąbrowa & 87 & $71: 29$ & $4: 96$ & 1,332 & $18.4 \pm 2.1$ & 54 & 22.0 \\
\hline Mierucin - UTM: YU04 18 & Dąbrowa & 82 & $48: 52$ & $53: 47$ & 1,266 & $24.2 \pm 3.4$ & 41 & 30.0 \\
\hline Ośniszczewko - UTM: CD31 31 & Dąbrowa Biskupia & 84 & 49:51 & $7: 93$ & 1,542 & $21.4 \pm 3.2$ & 47 & 38.0 \\
\hline Ostromecko - UTM: CD19 32 & Dąbrowa Chełmińska & 57 & 23:77 & $9: 91$ & 1,171 & $23.7 \pm 4.6$ & 42 & 31.0 \\
\hline Dębowa Łąka - UTM: CE70 22 & Dębowa Łąka & 74 & 18:82 & $1: 99$ & 1,733 & $21.8 \pm 3.5$ & 45 & 7.0 \\
\hline Niedźwiedź - UTM: CE60 82 & Dębowa Łąka & 114 & $33: 67$ & $4: 96$ & 2,338 & $23.1 \pm 2.6$ & 43 & 8.5 \\
\hline Gałczewko - UTM: CD79 02 & Golub-Dobrzyń & 105 & $71: 29$ & - & - & - & - & 26.0 \\
\hline Gałczewko II - UTM: CD79 02 & Golub-Dobrzyń & 104 & $71: 29$ & $8: 92$ & 1,844 & $21.8 \pm 2.7$ & 46 & 8.1 \\
\hline Inowrocław - UTM: CD13 28 & Inowrocław & 53 & $51: 49$ & - & - & - & - & 6.0 \\
\hline $\begin{array}{l}\text { Jabłonowo Pomorskie - UTM: } \\
\text { CE71 } 57\end{array}$ & Jabłonowo Pomorskie & 77 & $61: 39$ & - & - & - & - & 26.3 \\
\hline $\begin{array}{l}\text { Jabłonowo Pomorskie II - } \\
\text { UTM: CE71 } 57\end{array}$ & Jabłonowo Pomorskie & 78 & 38:62 & $10: 90$ & 1,401 & $19.8 \pm 2.0$ & 50 & 26.3 \\
\hline Janikowo - UTM: CD04 36 & Janikowo & 75 & $67: 33$ & $16: 84$ & 1,289 & $20.5 \pm 2.3$ & 49 & 21.9 \\
\hline Kołdrąb - UTM: XU44 35 & Janowiec Wielkopolski & 118 & $36: 64$ & $16: 84$ & 2,261 & $21.7 \pm 2.9$ & 46 & 29.4 \\
\hline Łopienno - UTM: XU64 73 & Janowiec Wielkopolski & 60 & 38:62 & $35: 65$ & 1,151 & $21.8 \pm 2.9$ & 46 & 32.4 \\
\hline Żurawia - UTM: XU67 74 & Kcynia & 40 & $67: 33$ & $15: 85$ & 651 & $21.1 \pm 3.6$ & 47 & 35.0 \\
\hline Wtelno - UTM: XV93 50 & Koronowo & 52 & $17: 83$ & $16: 84$ & 1,051 & $21.2 \pm 2.6$ & 47 & 37.6 \\
\hline Frydrychowo - UTM: CD69 12 & Kowalewo Pomorskie & 148 & $36: 64$ & $3: 97$ & 3,275 & $25.4 \pm 2.7$ & 46 & 26.3 \\
\hline Kobylniki - CD 1470 & Kruszwica & 162 & $49: 51$ & - & - & - & - & 18.9 \\
\hline Kruszwica - UTM: CD10 18 & Kruszwica & 159 & 30:70 & & & & & 18.6 \\
\hline Piaski - UTM: CD24 50 & Kruszwica & 58 & 22:78 & $4: 96$ & 1,315 & $25 \pm 3.7$ & 40 & 39.4 \\
\hline Rożniaty - UTM: CD24 50 & Kruszwica & 81 & $23: 77$ & - & - & - & - & 9.5 \\
\hline Jankowo - UTM: CD02 67 & Pakość & 68 & 34:66 & 18:82 & 1,210 & $19.9 \pm 3.2$ & 50 & 39.4 \\
\hline Lipno - UTM: CD77 40 & Lipno & 48 & $52: 48$ & $17: 83$ & 712 & $19 \pm 3.7$ & 53 & 16.1 \\
\hline Jankowice - UTM: CD14 83 & Łasin & 97 & $33: 67$ & $5: 95$ & 2,044 & $23.6 \pm 3.5$ & 42 & 56.9 \\
\hline Łabiszyn - XU97 70 & Łabiszyn & 174 & $19: 81$ & - & - & - & - & 16.5 \\
\hline Załachowo - UTM: XU94 07 & Łabiszyn & 100 & $12: 88$ & - & - & - & - & 11.7 \\
\hline Mogilno I - UTM: YU03 26 & Mogilno & 148 & $80: 20$ & $0: 100$ & 1,218 & $21.4 \pm 3.4$ & 47 & 61.6 \\
\hline Mogilno II - UTM: YU03 26 & Mogilno & 66 & $77: 23$ & - & - & - & - & 7.7 \\
\hline Mrocza - UTM: XV70 43 & Mrocza & 104 & $41: 59$ & $7: 93$ & 2,023 & $23.6 \pm 3.7$ & 42 & 53.4 \\
\hline Rybitwy - UTM: CD05 02 & Pakość & 39 & $21: 79$ & $19: 81$ & 733 & $19.9 \pm 2.7$ & 50 & 34.1 \\
\hline $\begin{array}{l}\text { Piotrków Kujawski - UTM: } \\
\text { CD } 3040\end{array}$ & Piotrków Kujawski & 77 & $25: 75$ & - & - & - & - & 9.0 \\
\hline Płużnica - UTM: CE50 27 & Płużnica & 72 & $49: 51$ & $3: 97$ & 1,322 & $21.6 \pm 2.7$ & - & 6.4 \\
\hline Szafarnia - UTM: CD78 56 & Radomin & 74 & $26: 74$ & $18: 82$ & 1,725 & $25.9 \pm 4.4$ & 39 & 6.5 \\
\hline Wąbrzeźno - UTM: CE63 03 & Wąbrzeźno & 114 & $50: 50$ & $14: 86$ & 2,056 & $21.3 \pm 1.8$ & 47 & 8.5 \\
\hline Wielgie - UTM: CD77 23 & Zbójno & 97 & 11:89 & $36: 64$ & 2,581 & $27.7 \pm 5.3$ & 36 & 7.7 \\
\hline
\end{tabular}


cyn (10). In communes Mrocza, Sadki, Toruń and Pakość nine purchase centres were opened. Twelve communes had 7-8 purchase centres each, and 13 communes - 4-6 purchase centres each. Communes with three purchase centres were the most numerous - 32. The remaining 20 communes had 1-2 purchase centres each.

\section{CHARACTERISTICS OF SELECTED ROMAN SNAILS POPULATIONS IN KUJAWSKO-POMORSKIE VOIVODESHIP}

Among the 281 examined plots in Kujawsko-Pomorskie voivodeship, 175 held Roman snail $(62 \%)$. Only 53 plots (19\%), with 30 individuals each, can be regarded as commercially interesting (Table 2 ). In 105 plots (37\%) only one to ten individuals were found. In 105 plots no Roman snail was found (Fig. 7).

The Roman snail density in 40 plots selected among the richest plots in Kujawsko-Pomorskie voivodeship ranged from six to 62 individuals per 1 are (mean 23.33 \pm 14.50 ). Adult indviduals in these populations reached a weight ranging from 18.4 to $27.7 \mathrm{~g}$ (mean 22.29 \pm 2.21 ). In these populations on average 36 to 54 individuals (mean $45.4 \pm 4.3$ ) were needed to harvest $1 \mathrm{~kg}$ of Roman snail.

The age structure in the examined populations varied. Adults dominated in 27 populations $(68 \%)$,

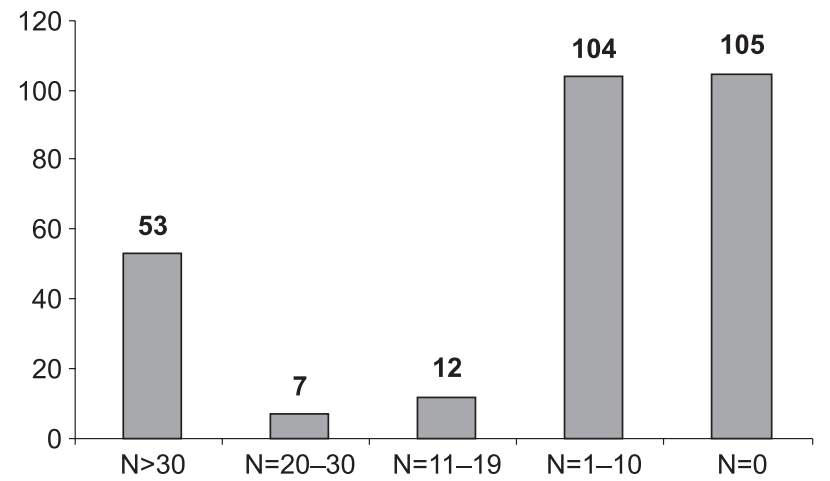

Fig. 7. Occurence of Roman snail populations in Kujawsko-Pomorskie voivodeship. $\mathrm{N}=$ number of individuals, $\mathrm{Y}$ axis - number of populations in particular abundance groups

while the proportion of juveniles varied among populations and ranged from 11 to $80 \%$.

The proportion of snails with shell diameter exceeding $30 \mathrm{~mm}$ and snails below the standard size in the studied populations was also assessed. The proportion may indicate dwarfing or predominance of slender, high-spired individuals which may be a side-effect of selection during intensive exploitation. In most of the examined populations the proportion of adults below the standard size did not exceed 20\%; it ranged from 0 to $53 \%$. Only in three populations (Mierucin, Łopienno, Wielgie) a tendency to dwarfing was distinct, with small adults $(<30 \mathrm{~mm})$ exceeding $30 \%$.

\section{DISCUSSION}

The greatest problem at present is the estimation of the actual abundance and biomass of Roman snail over a large area of Kujawsko-Pomorskie voivodeship. All the previously used methods were very imprecise. The first (and only) attempt at an assessment of the Roman snail resources in Poland was STEPCZAK's (1976) study. Based on the UTM square grid $(25 \times 25$ $\mathrm{km}$ ) and the number of Roman snail localities in each square, the author presented the density of Roman snail records in the whole of Poland. The basic data for the map of the density of Roman snail records were derived from inquiries in schools and purchase centres, as well as from literature and collections of the Department of General Zoology, Adam Mickiewicz University. STE_PCZAK (1976) distinguished four categories of locality distribution, from no or very rare occurrence of the snail to six or more records per square. It seems that the method is biased, because of the uneven collecting effort in individual squares, ignoring the propotion of adequate Roman snail habitats in each and the absence of direct verification of the inquiry results. The data should thus be regarded as tentative. The number of records in each square does not reflect the population density or fluctuations in population abundance. However, the com-

parison of current observations and STEPCZAK's (1976) results, presented by KoŁODZIEJCZYK \& SKAWINA (2009) for the northern part of Mazovia, shows that they are well compatible. Their observations suggest that in the studied area the Roman snail is very rare and has shown no expansion tendency at least for 35-45 years.

The greatest problem with the estimation the Roman snail resources is the lack of studies on the precise boundaries and real abundance of its populations. The estimates based on single samples do not provide a basis even for a rough estimate of the snail's abundance and biomass. It is practically impossible to gain such information without prior ascertainment of the area occupied by the population and precise whole-season observations of marked individuals. It is not exactly known if within an area exceeding 10 ha the snail forms a large metapopulation or several isolated populations.

Collecting has a significant impact on the density of snail populations, and it affects different age classes in different ways (ANDREEV 2006). Based on studies in Moldova, ANDREEV (2006) found that the mean density of exploited Roman snail populations could drop even seven times. Literature information on the de- 
gree to which collectors limit the abundance of natural populations is scarce. The absence of these two basic pieces of information makes the exploitation quota inaccurate, since they are issued each year, based only on a very rough assessment which may even lead to local extinctions of the species. It should be borne in mind that Roman snail plays an important role in terrestial ecosystems, providing food and shelter for a large number of invertebrates and vertebrates (UVALIEVA 1990). Depending on its abundance, it accelerates the litter decomposition even up to several times (STRIGANOVA 1975, 1980), and produces considerable quantities of soil-fertilising faeces. It is estimated that the snails occurring in $1 \mathrm{ha}$, with a biomass of $34 \mathrm{~kg}$, are able to consume more than 650 $\mathrm{kg}$ plant biomass during their entire active period (TUŘCEK 1970a, b).

The main aim of the study was to assess the Roman snail resources in Kujawsko-Pomorskie voivodeship and express an opinion on their possible commercial exploitation. Is the Roman snail common in the voivodeship? Its frequency in the samples, $81 \%$, obtained in our inventory, seems to indicate that it is common. According to our results the low density of Roman snail in most of the studied populations (usually single individuals were found) indicates that from the scientific point of view the most rational solution would be to suspend commercial exploitation in 2010 and continue monitoring, while issuing permissions for limited collecting should be postponed till 2011. This would make it possible to assess the non-exploited populations in more detail (population structure, abundance, density etc.), and then estimate the losses caused by exploitation in selected, monitored populations. This in turn would make it possible to set acceptable quota of annual commercial collecting for various parts of the voivodeship.

\section{REFERENCES}

ANDREEV N. 2006. Assessment of the status of wild populations of land snail (escargot) Helix pomatia L. in Moldova: The effect of exploitation. Biodiversity and Conserv. 15: 2957-2970.

BIULETYN CIS (BIULETYN CENTRALNEGO INSPEKTORATU STANDARYZACJI) 1962. Ślimak winniczek. Warszawa.

KoŁODZIEJCZYK A., SKAWINA A. 2009. The Roman Snail (Helix pomatia Linneus, 1758) in Northern Masovia. Folia Malacol. 17: 69-72.

STĘPCZAK K. 1976. Distribution, abundance and protection of the Roman snail (Helix pomatia) in Poland. Wyd. Nauk. UAM, Poznań, Ser. zool. 3: 1-68.

STRIGANOVA B. P. 1975. Roly pochvoobitayushchikh bezpozvonochnykh v destruktsionnykh procesakh. Rol zhivotnykh $\mathrm{v}$ funktsionirovanyi ekosistem. Nauka, Moskva: 58-61.
At the same time, considering social and economic factors, it was decided, for the communes with rich Roman snail populations (Fig. 1, communes marked with brown), to issue purchase permissions for 2010 , for quantities not exceeding the quantities of Roman snail bought by the purchase centres of 2008 .

If climatic conditions in the spring-summer season of 2010 proved favourable to the Roman snail (high humidity, optimum temperature, rich herb vegetation), in 2011 it would be possible to issue permissions to harvest the snail at the same quantity. However, it will be impossible to assess the Roman snail resources and possibly suspend exploitation or determine its quota in 2012, without comparative studies estimating the effect of exploitation in the previous years. It is recommended to continue monitoring for at least four years i.e. the minimum period required by this year's hatchlings to reach commercial size.

Further detailed studies are necessary, especially on the real assessment of Roman snail resources in Poland and functioning of its populations in various conditions. They will not only make possible actions to protect the species, but also to specify precise quota of commercial collecting to prevent overexploitation.

\section{ACKNOWLEDGEMENTS}

Authors express their sincere thanks to all persons who helped with the field work, especially Dr. JózEF Musiat, Dr. Michat KupczYK and Mr. Piotr MroczYK. Out thanks go to Mr. LECH KACZMAREK, M. Sc., Head of the Ecological Station in Jeziory and to Mr. RAFAŁ BAJACZYK, M. Sc. for their help with maps and computer data base. The inventory was commissioned by the Regional Administration of Environment Protection in Bydgoszcz, whose staff helped us in all respects.

STRIGANOVA B. R. 1980. Pitanye pochvennykh saprofagov. Nauka, Moskva.

TUŘCEK F. J. 1970a. Growth in the early juvenile Roman snail, Helix pomatia $\mathrm{L}$. and secondary netto production. Biologia 25: 555-558.

TUŘCEK F. J. 1970b. Studies on the ecology and production of the Roman snail Helix pomatia L. Biologia 25: 103-108.

URBAŃSKI J. 1963. Roman snail, Helix pomatia L. - systematics, biology, economical significance and protection. Ochr. Przyr. 29: 215-254.

UVALIEVA C.C. 1990. Nazemnye mollyuski Kazakhstana i sopredelnykh stran. Nauka Kaz, Alma Ata.

Received: March 12th, 2010

Accepted: June 15th, 2010 
